\title{
SICKLE CELL DISEASE: REAPPRAISAL OF THE ROLE OF FOETAL HAEMOGLOBIN LEVELS IN THE FREQUENCY OF VASO-OCCLUSIVE CRISIS
}

\author{
C. ANTWI-BOASIAKO ${ }^{1}$, E. FRIMPONG ${ }^{1}$, G. K. ABABIO ${ }^{2}$, B. DZUDZOR ${ }^{2}$, I. EKEM ${ }^{3}$, B. \\ GYAN $^{4}$, N.A SODZI-TETTEY ${ }^{1}$ and D. A. ANTWI ${ }^{1}$ \\ ${ }^{1}$ Department of Physiology, ${ }^{2}$ Department of Medical Biochemistry and ${ }^{3}$ Department of Haematology, Univer- \\ sity of Ghana Medical School, P. O. Box 4236, Accra, Ghana ${ }^{4}$ Department of Immunology, Noguchi Memorial \\ Institute for Medical research, College of Health Sciences, University of Ghana, Legon, Ghana
}

DOI: $h t t p: / / d x$. doi.org/10.4314/gmj.v49i2.7

Corresponding Author: C. Antwi-Boasiako

E-Mail: antwiboasiako@chs.edu.gh

Conflict of Interest: None declared

\section{SUMMARY}

Background: Foetal haemoglobin has been implicated in the modulation of sickle cell crisis. Its level is generally inversely proportional to the severity of sickle cell disease (SCD) for a given sickle cell phenotypes. The main aim of therapy for vaso-occlusive crisis (VOC), which is the hallmark of SCD, is to reduce the chances of sickling through the prevention of polymerization of $\mathrm{HbS}$. One way of preventing this polymerization is by increasing foetal haemoglobin levels.

Objectives: To determine the relationship between $\mathrm{HbF}$ levels and the frequency of crisis in SCD patients in Ghana.

Method: A longitudinal retrospective survey covering a period of 30 months was carried out on adult SCD patients at the Sickle Cell Clinic of the Korle-Bu Teaching Hospital.

Results: Eighty-three adults aged 15 to 65 years made up of 40 males and 43 femalea were studied. Analysis of variance (ANOVA) gave significant results in $\mathrm{Hb}$ and $\mathrm{HbF}$ levels. Higher $\mathrm{HbF}$ levels were positively related to less frequent crisis and were significantly high in SCD patients than in controls. HbF effects on the clinical manifestations on SCD were variable.

Conclusion: Threshold values of $\mathrm{HbF}$ play a role in reducing the frequency of vaso-occlusive crisis in SCD patients and this finding contributes to the body of available literature on SCD severity. However our work does not give the apparent threshold level of helpful HBF Level in SCD.

Keywords: Haemoglobin F, Frequency of crisis, sickle cell disease.

\section{INTRODUCTION}

Sickle cell disease (SCD) is a major genetic disorder in tropical Africa. ${ }^{1}$ In Ghana the prevalence rate is $1.9 \%$ of all births per year ${ }^{2}$ and is responsible for significantly

high rate of morbidity and mortality in Ghana. SCD placed $37^{\text {th }}$ and $36^{\text {th }}$ positions in the years 2002 and 2003 respectively on the out-patient morbidity reports compiled by the Ghana Health Service. Even though clinical manifestation of SCD displays a wide array of symptoms, recurrent attacks of VOC are responsible for most of the morbidity and mortality in SCD. ${ }^{2,3}$

Pathophysiologically, oxygenated Haemoglobin A ( $\mathrm{HbA})$ and Haemoglobin $\mathrm{S}(\mathrm{HbS})$ has the same solubility, but on deoxygenation, $\mathrm{HbS}$ is about 100 times less soluble. ${ }^{3}$ The deoxygenated Haemoglobin S polymerizes by sticking to each other to form long strands, which stretches the membrane of the red blood cell. ${ }^{4,5} 6$ This defect causes polymerization of haemoglobin molecules and erythrocyte sickling under hypoxic conditions $^{7,8,2}$ leading to VOC. VOC is caused by sickled red blood cells which obstruct capillaries and restrict blood flow to an organ, resulting in ischemia, pain, and organ damage $e^{9,10}$ and it is responsible for the high rate of morbidity ${ }^{3}$ and mortality ${ }^{2}$ in SCD.

The disease severity depends primarily on the genotype which is ranked as $\mathrm{HbSS}>\mathrm{HbS} / \beta^{\circ}$-thalassemia $>$ $\mathrm{HbSC}>\mathrm{HbS} / \beta^{+}$-thalassemia. ${ }^{11}$ The severity of the disease is also related to $\beta$-globin haplotypes, possibly due to variations in hemoglobin level and fetal hemoglobin concentrations. Nevertheless, haplotypes of the $\beta$ globin gene cluster and $\alpha$-globin complement affecting the expression of factors such as $\mathrm{HbF}$, modulate the disease severity. ${ }^{12}$ Five haplotypes of the $\mathrm{HbS}$ allele have been identified from various populations based on two polymorphic clusters. ${ }^{12}$

These clusters are thought to correlate with hematological markers and $\mathrm{HbF}$ gene expression leading to a decreasing disease severity as Bantu $>$ Cameroon $>$ Benin $>$ Arab Indian $>$ Senegal $^{13}$ and are geographically restricted. 
However, work done by Inati et al., and a recent work ${ }^{14}$ indicated that there are still atypical haplotypes that do not conform to literature. ${ }^{15}$ For instance, in one report from Lebanon, high $\mathrm{HbF}$ concentration was associated with increased disease severity ${ }^{16}$, a finding which warrants further investigation.

Some genetic and environmental factors have been identified that ameliorate the severity of the SCD condition. The most important of these is a high level of hemoglobin $\mathrm{F}(\mathrm{HbF})$ in the erythrocytes. ${ }^{17}$ The first insight into the role of foetal hemoglobin in the clinical manifestations of SCD was made by a pediatrician, Janet Watson. ${ }^{18}$ Watson and her colleagues at a New York hospital noted that babies with SCD rarely had manifestations of the condition in their first year of life. ${ }^{18}$ They proposed that the high level of $\mathrm{HbF}$ in the red cells, which persists during the first year of life, somehow protected the infant. Foetal $\mathrm{Hb}$ levels decline to their low levels of less than $2 \%$ six months after birth. ${ }^{19}$ The childhood manifestations of SCD are seen thereafter.

Clinical observations have also confirmed that increased foetal haemoglobin concentrations have beneficial effects in SCD. ${ }^{20,21,22}$ Patients with SCD who have elevated $\mathrm{HbF}$ levels have fewer painful crises and improved survival ${ }^{20}$ as shown by studies that fetal haemoglobin, which lacks $\beta$-globin chains, inhibits sickling in vitro by interfering with the polymerization of haemoglobin $\mathrm{S}^{23,24}$. Since polymerization of deoxy$\mathrm{HbS}$ is the signal event in the pathogenesis of $\mathrm{SCD}^{4}$, $\mathrm{HbF}$ could effectively prevent disease manifestation.

Patients with sickle cell disease who also have hereditary persistence of foetal haemoglobin (HPFH) often have few if any symptoms ${ }^{19}$. In these individuals, $\mathrm{HbF}$ usually comprises greater than $20 \%$ of the haemoglobin in the erythrocytes. It has been documented that increased $\mathrm{HbF}$ levels ameliorate the severity and frequency of painful crisis in SCD patients. ${ }^{20,21,22}$ Studies within populations of African origin have also shown that high $\mathrm{HbF}$ levels are associated with milder disease. $^{26,27,28}$

However, the role of $\mathrm{HbF}$ on the clinical sub phenotype is variable and inconsistent such that even levels nearing $20 \%$ may be found in patients with severe disease. The threshold for significant reduction in acute episodes of pain, chest syndromes, and priapism is $20 \%$, and for organ damage, $10 \%$.

A retrospective study in Jamaica did not find significant difference in painful episodes or acute chest syndrome between different levels of $\mathrm{HbF}$ level, ${ }^{29}$ whilst no protective effect of $\mathrm{HbF}$ was found in studies by
Baum. ${ }^{30}$ However, a clear protective effect was found in the Co-operative Study in the USA ${ }^{17,21,31}$ also found no linear relationship between $\mathrm{HbF}$ and clinical severity, but proposed that there were 'threshold levels' above which $\mathrm{HbF}$ was an ameliorating factor $(10 \%$ for stroke, $20 \%$ for recurrent events such as painful crises).

Several cytotoxic agents such as hydroxyurea ${ }^{25,32}$ and 5-azacytidine ${ }^{33,34}$ enhance the levels of foetal hemoglobin developing erythroid cells. Hydroxyurea has been administered to patients with sickle cell disease in an effort to enhance foetal hemoglobin production. ${ }^{35}$

Hydroxyurea induces foetal haemoglobin production ${ }^{35-}$ ${ }^{38}$ increases the red cell mean corpuscular volume, and reduces the number of dense cells and irreversibly sickled cells in the circulation, ${ }^{24}$ thereby reducing morbidity and mortality in SCD patients. ${ }^{38}$ Treatment with hydroxyurea caused a $44 \%$ reduction in the median annual rate of painful crises in patients with $\mathrm{SCD}^{23}$

The possible benefit of $\mathrm{HbF}$ in reducing the frequency of crisis in SCD in Ghana is not clear. This study will give a better understanding of the relationship between $\mathrm{HbF}$ levels and the frequency of crisis in SCD.

\section{MATERIALS AND METHODS}

The study was limited to patients with the HbSS and HbSC phenotypes. Voluntary blood donors at the National blood bank, Korle-bu Teaching Hospital were recruited for the study. Blood samples were screened for Sickle cell haemoglobin and those with sickle cell trait (HbAS as well as HbAC) were excluded. Five ml of venous blood was collected from the subjects into EDTA tubes for sickling test, Haemoglobin Electrophoresis, $\mathrm{HbF}$ and haemoglobin concentration determinations.

Sickling test for controls (screening) was by sodium metabisulfitemethod. $^{40}$ Measurement of $\mathrm{HbF}$ levels were by alkaline denaturation method as described by Singer and others. ${ }^{41}$ VOC was clinically defined as pains in the bones, muscles and joints not attributable to any other cause and requiring parenteral analgesia and admitted in the Centre for more than an hour. The Frequencies of VOC was rerecorded by the number of times patients were hospitalized during the period of the study by a questionnaire.

All subjects gave their informed consent. Ethical clearance for this study was given by the Ethical and protocol review Committee of the University of Ghana Medical School. 


\section{RESULTS}

Paired and unpaired student t-test was used to compare differences between and within sex-matched means in the groups, but these were not statistically significant. However, analysis of variance (ANOVA) gave significant results in $\mathrm{Hb}$ and $\mathrm{HbF}$ levels (Table 1).

Table 1 Haemorheological parameters in the studied groups

\begin{tabular}{|l|l|l|l|l|}
\hline Males & $\mathbf{S C}_{20}$ & $\mathbf{S S}_{16}$ & $\mathbf{A A}_{83}$ & p-values \\
\hline Age & $29.6 \pm 13.1^{*}$ & $25.3 \pm 11.5$ & $30.0 \pm 7.0$ & 0.159 \\
\hline $\mathrm{Hb}$ & $11.1 \pm 3.8$ & $7.9 \pm 2.6$ & $14.0 \pm 1.7$ & 0.000 \\
\hline $\mathrm{HbF}$ & $8.2 \pm 2.8$ & $8.4 \pm 2.9$ & $1.1 \pm 0.5$ & 0.000 \\
\hline Females & $\mathrm{SC}_{26}$ & $\mathrm{SS}_{18}$ & $\mathrm{AA}_{19}$ & \\
\hline $\mathrm{Age}$ & $23.1 \pm 10.9$ & $25.1 \pm 11.4$ & $28.8 \pm 7.2$ & 0.187 \\
\hline $\mathrm{Hb}$ & $11.2 \pm 2.3$ & $8.0 \pm 2.8$ & $14.1 \pm 2.1$ & 0.000 \\
\hline $\mathrm{HbF}$ & $8.0 \pm 4.6$ & $8.3 \pm 3.0$ & $1.1 \pm 0.5$ & 0.000 \\
\hline
\end{tabular}

* Mean standard deviation; Sickle cell patients appear younger than controls but this was not statistically significant after analysis of variance was done; p-values less than 0.05 were said to be significant.

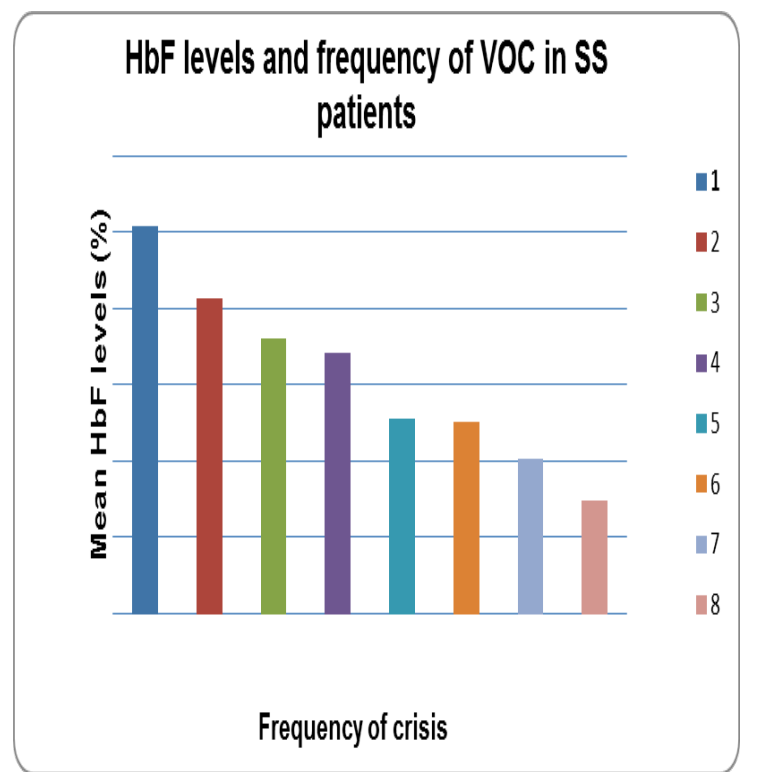

Figure $1 \mathrm{Hb} F$ levels and frequency of vaso=occlusive crises in sickle cell $\mathrm{Hb} \mathrm{SS}$ disease patients.

$\mathrm{HbF}$ effects on the clinical manifestations on SCD were slightly variable (Figures1 and 2).This conforms to previous studies that stated 'threshold levels' above which $\mathrm{HbF}$ could be an ameliorating factor. ${ }^{21,29-31}$
The higher the HbF level in an individual, the lower the frequency of crisis one experiences.

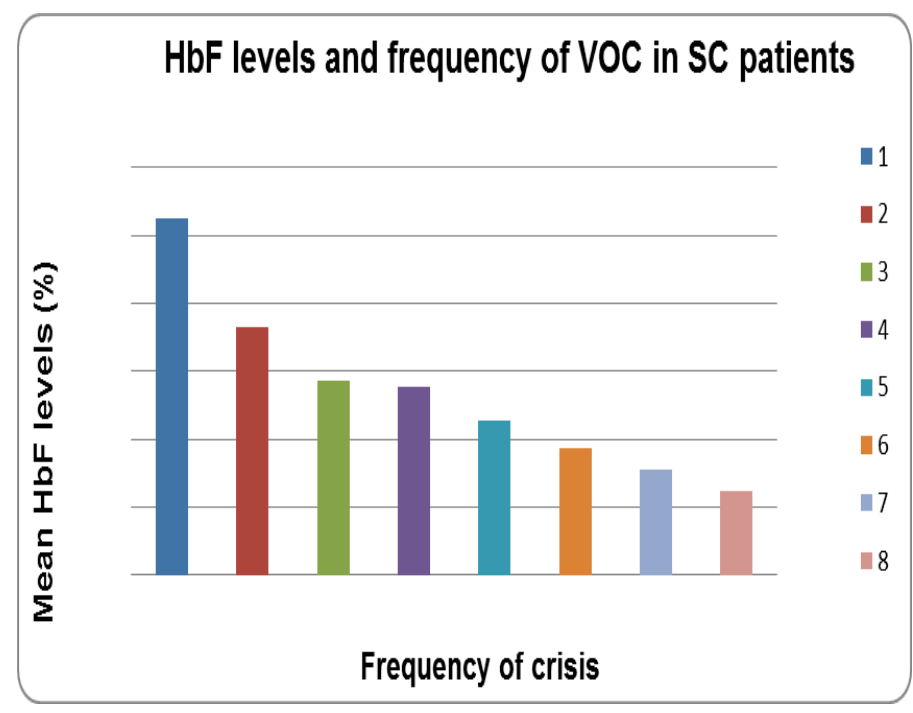

Figure $2 \mathrm{Hb} F$ levels and frequency of vaso=occlusive crises in sickle cell $\mathrm{Hb} \mathrm{SC}$ disease patients.

HbF appears to benefit some complications of disease more than others (Figures 1 and 2). This might be related to the premature destruction of erythrocytes that do not contain $\mathrm{HbF}$, even though the total HbF concentration was high.

\section{DISCUSSION}

In this study, $\mathrm{HbF}$ levels were significantly higher in SCD patients than in controls. This was consistent with the finding of Konotey-Ahulu. ${ }^{1}$ The high levels of $\mathrm{HbF}$ in SCD patients may suggest that increased foetal haemoglobin concentrations may have beneficial effects in $\mathrm{SCD}^{22,24}$ This is because increased cellular levels of $\mathrm{HbF}$ reduces the tendency of deoxygenated $\mathrm{HbS}$ to polymerize since $\mathrm{HbF}$ interferes with the intracellular polymerization of $\mathrm{HbS}^{42}$. Therefore, $\mathrm{HbF}$ confers a survival advantage to erythrocytes in proportion to the amount of $\mathrm{HbF}$ present ${ }^{43}$ and has beneficial effects on patients with SCD.

$\mathrm{HbF}$ effects on the clinical manifestations on SCD were slightly variable. This conformed to previous studies that stated 'threshold levels' above which $\mathrm{HbF}$ could be an ameliorating factor. ${ }^{21,25-26,29-31}$ The particular threshold is still a subject of concern.

Furthermore, haplotypes of the $\beta$-globin gene cluster and $\alpha$-globin complement affecting the expression of factors such as $\mathrm{HbF}$, also modulate SCD severity. Haplotypes of the $\mathrm{HbS}$ allele have been identified from various populations of distinct polymorphic clusters. 
These clusters are thought to correlate with hematological markers and HbF gene expression which impact on disease severity. To shed more light on these, more sensitive studies like high performance liquid chromatography for $\mathrm{HbF}$ determination and targeted genomic analysis are needed.

A limitation of our study was the small sample size that was comparable to literature cited. Nonetheless, these findings add to the small body of literature concerning SCD severity.

\section{CONCLUSION}

Threshold values of $\mathrm{HbF}$ play a role in reducing the frequency of vaso-occlusive crisis in SCD patients and this finding contributes to the body of available literature on SCD severity. However our work does not give the apparent threshold level of helpful $\mathrm{HbF}$ Level in SCD.

\section{ACKNOWLEDGEMENT}

We are grateful to the assistance and co-operation of the Sickle Cell Unit, Korle - Bu Teaching Hospital.

\section{REFERENCES}

1. Konotey-Ahulu FID. The Sickle Cell Disease Patient. London and Basingstoke: Macmillan Pub1sihing Company; 1991. p.1-304.

2. Bunn FH. Pathogenesis and treatment of sickle cell disease. New Engl J Med 1997; 302:762-768.

3. Palmer RM, Ferrige AG and Moncada S,.Nitric oxide release accounts for the biological activity of endothelium-derived relaxing factor. Nature 1987; 327:524-6.

4. Ohene-Frempong K, Oduro J, Tetteh H, Nkrumah F. Screening newborns for sickle cell disease in Ghana. Paediatrics 2008; 121:S120-S121.

5. Eaton WA and Hofrichter J. Sickle cell hemoglobin polymerization. Advances in Protein Chemistry 1990; 40:63-279.

6. Maier-Redelsperger M, Noguchi CT, De Montalembert M, Rodgers GP, Schechter AN, Gourbil A, Blanchard D, Jais JP, Ducrocq R, Peltier JY. Variation in fetal hemoglobin parameters and predicted hemoglobin S polymerization in sickle cell children in the first two years of life: Parisian Prospective Study on Sickle Cell Disease. Blood 1994; 84(9): 3182-8.

7. Bain BJ. Other significant haemoglobinopathies. In: Haemoglobinopathy Diagnosis $\left(2^{\text {nd }} e d\right)$. Malden, MA: Blackwell Publishing; 2006:201211.

8. Embury, S.H., Hebbel, R.P., Mohandas, N., Steinberg, M.H. Sickle cell disease. Basic princi- ples and clinical practice. 1994; New York: Raven Press;

9. Robert P. Hebbel. Adhesive Interactions of Sickle Erythrocytes with Endothelium J. Clin. Invest. 1997; 99 (11); 2561-2564

10. Ned JY. The inheritance of sickle cell anaemia. Science 1949; 110: 64-6

11. Ashley-Koch A, Yang Q, Olney RS. Sickle hemoglobin (Hb S) allele and sickle cell disease: A HuGE review. American Journal of Epidemiology. 2000; 151(9): 839-845.

12. Idowu A, Abdulrahman A, Nadia S, Duyen N, Clinton T. Baldwin, Paola S, David HKC, Martin $\mathrm{H}$ S. Fetal hemoglobin in sickle cell anemia. Blood. 2011; 118(1): 19-27.

13. Stuart MJ, Nagel RL. Sickle-cell disease. Lancet. 2004; 364(9442): 1343-60.

14. Ababio, G., Personal Communication with permission.

15. Liu Y, Yi-Ju L, Glen AS, Andrew SA, Jung-Ying TA. Regression-based Association Test for Casecontrol Studies that Uses Inferred Ancestral Haplotype Similarity. Annals of Human Genetics 2009; 73,520-526

16. Inati A, Taher W, Bou AWS, Koussa H, Kaspar H, Shbaklo P. Zalloua A. $\beta$-Globin gene cluster haplotypes and $\mathrm{HbF}$ levels are not the only modulators of sickle cell disease in Lebanon. European Journal of Haematology 2003; 70 (2). 79-83

17. Ingram VM. A specific chemical difference between the globins of normal human and sickle cell anemia hemoglobin. Nature 1956; 178: 792-794.

18. Kaul DK, Fabry ME, Nagel RL.The pathophysiology of vascular obstruction in the sickle syndromes. Blood Rev.1996; 10:29 - 44.

19. Platt OS, Thorington BD, Brambilla DJ, Milner PF, Vichinsky E and Kinney TR. Pain in sickle cell disease. Rates and risk factors. New England Journal of Medicine 1991; 325: 11-16.

20. Watson J. Study of sickling of young erythrocytes in sickle cell anemia. Blood 1948; 94:468-9.

21. Edoh D, Antwi-Bosaiko C and Amuzu D. Fetal hemoglobin during infancy and in sickle cell adults. Afr Health Sci 2006; 6(1): 51-4.

22. Perrine RP, Brown MJ, Clegg JB, Weatherall DJ and May A. Benign sickle cell disease. Lancet 1972; 2:1163-1167.

23. Powars DR, Weiss JN, Chan LS and Schroeder WA. Is there a threshold level of fetal hemoglobin that ameliorates morbidity in sickle cell disease? Blood 1984; 63:921-926.

24. Charache S. Fetal hemoglobin, sickling, and sickle cell disease. Adv Pediatr 1990; 37:1-31.

25. Charache S, Terrin M, Moore R, Dover G, Barton F, Eckert S, McMahon R and Bonds D. Effect of hydroxyurea on the frequency of painful crises in 
sickle cell anemia. Investigators of the Multicenter Study of Hydroxyurea in Sickle Cell Anemia. N Engl J Med 1995; 332, 1317-22.

26. Goldberg M, Brugnara C, Dover G, Schapira L, Lacroix L and Bunn H. Hydroxyurea and erythropoietin therapy in sickle cell anemia. Seminars in Oncology1992; 19, 74-81.

27. Stamatoyannopoulos G, Wood W, Papayannopoulou $\mathrm{T}$ and Nute P. A new form of hereditary persistence of fetal hemoglobin in blacks and its association with sickle cell trait. Blood 1975; 46, 683-92.

28. Jackson JF, Odom JL and Bell WN. Amelioration of sickle cell disease by persistent fetal hemoglobin. Journal of American Medical Association.1961; 177, 867-869.

29. Serjeant GR. Fetal hemoglobin in homozygous sickle cell disease. Clinical Haematology 1975; 4: 109-122.

30. Odenheimer DJ, Whitten CF, Sarnaik SA and Sing CF. Heterogeneity of sickle cell anaemia based on a profile of haematological variables. American Journal of Human Genetics. 1983; 35; 1224-1240.

31. Bailey K, Morri JS, Thomas P and Serjeant GR. Fetal hemoglobin and early manifestations of homozygous sickle cell disease. Archives of Disease of Childhood. 1992; 67: 517-520.

32. Baum KF, Dunn DT, Maude GH and Serjeant GR. The pain crisis of homozygous sickle cell disease: a study of risk factors. Archives of Internal Medicine.1987; 147: 1231-1234.

33. Powars DR, Weiss JN, Chan LS and Schroeder WA. Is there a threshold level of fetal hemoglobin that ameliorates morbidity in sickle cell disease? Blood 1984; 63:921-926.

34. Platt O, Orkin S, Dover G, Beardsley G, Miller B, and Nathan D. Hydroxyureaenhances fetal hemoglobin production in sickle cell anemia. J Clin Invest. $1984 ; 74,652-656$.
35. Lavelle D, DeSimone J, Heller P, Zwiers D, Hall L. On the mechanism of HbF elevations in the baboon by erythropoietic stress and pharmacologic manipulation. Blood 1986; 67:1083-1089.

36. DeSimone J, Heller P, Hall L, Zwiers D. 5Azacytidine stimulates fetal hemoglobin ( $\mathrm{HbF})$ synthesis in anemic baboons. Proc Natl Acad Sci. 1982; 79:4428-4431.

37. Rodgers GP, Dover GJ and Noguchi CT. Hematological responses of patients with sickle cell disease to treatment with hydroxyurea. $N$ Engl $J$ Med. 1990; 322:1037-1045.

38. Charache S. Mechanism of action of Hydroxyurea in the management of sickle cell anaemia in adults. Haematol. 1997; 34: 15-21.

39. Steinberg MH, Lu Z, Barton FB, Terrin ML, Charache $S$ and Dover GJ. Fetal hemoglobin in sickle cell anemia: determinants of response to hydroxyurea: multi-center study of hydroxyurea. Blood. 1997; 89:1078-1088.

40. Steinberg MH,Brugnara C. Pathophysiologicalbased approaches to treatment of sickle cell disease. Annu Rev Med. 2003; 54:89-112.

41. Vichinsky E. New therapies in sickle cell disease. Lancet. 2002; 360(9333): 629-31.

42. Dacie JV and Lewis SM. Practical hematology, Eighth Edition. 1994; 258,266.

43. Singer K, Chernoff AI and Singer L. Studies on abnormal hemoglobins. Their distribution in Sickle cell anemia and other hematologic disorders by means of alkali denaturation. Blood 1951; 6: 41328.

44. Bookchin RM, Nagel RL.Interactions between human hemoglobins: sickling and related phenomena. Semin Hematol. 1974; 11(4): 577-95 